steps. Finally, the party returned safely to the ship, and found that the Morning relief ship had arrived in McMurdo Sound. Mr. Armitage made a journey to the rvestward with a large party. After one or two failures he found a good route to the main ice cap over the surface of a glacier of great length. He gradually rose in altitude until he arrived on the inland plateau at a height of 8900 feet, and was thus the first to penetrate into the interior of Victoria Land.

The expedition had hoped to accompany the Morning home, and it was not until the end of February, 1903, that this was seen to be impossible, because of the condition of the ice. They expected the ice in the bay in which they lay to break up, but unfortunately it got so late that there was only one thing for the Morning to do, and that was to return. She got home with a good deal of difficulty, but the Discovery was forced to remain a second winter.

Captain Scott next made a sledging expedition in a westerly direction, reaching his "furthest west" point on November 30, 1903. The party had reached the top of a mountain range some 7000 feet above the sea-level when a blizzard came on and prevented further movement for six days. The party then set out westward, rising another 1500 feet, and for another week advanced over a huge plain that extended as far as the eye could reach. The temperature was forty degrees below zero, and the lips, nostrils, and cheeks of the party were blistered by the incessant wind from the west. The rarefied air, too, had a great effect in reducing staying power. On this expedition they reached a very interesting spot-that at which the compass pointed south instead of north. They had reached for the first time the line of no variation lying between the South Pole and the south magnetic pole.

By the middle of December, 1903, all the sledging parties were ordered to be back, in order that an attempt might be made to free the Discovery from the ice by sawing out a channel. The attempt to clear a channel had to be abandoned, but on January 15 the Morning and the Terra Nova were sighted. They brought word that unless the Discovery could be freed it must be abandoned, and to obviate this hard necessity blasting operations were undertaken. But by the end of January the ice began to break up of its own accord, and by the middle of February there was a clear channel for the Discovery, which was then free to start on its return voyage.

\section{MOUNT EVEREST: THE STORY OF A} LONG CONTROVERSY.

THE highest mountain in the world is situated in a country from which Europeans have with few exceptions been jealously excluded; and the recent visit to the capital of Nepal of an experienced British surveyor, equipped with instruments and with full permission to use them, is an event of no small interest in the annals of Himalayan geography. ${ }^{2}$ It is clear from Captain Wood's report that this event has been brought about by the personal intervention of Lord Curzon.

Suryeyors have penetrated the Himalayas east and west of Nepal into Sikkim and Kumaon, and have from these points of view been enabled to observe a few of the Nepalese peaks; but from flanking stations the ranges of mountains are seen " end on," and the nearer peaks shut out the more distant from view. The knowledge that we possess of the heights and positions of the peaks of the Nepalese Himalayas has consequently been obtained from observations taken with theodolites at stations situated in the plains of Bengal and Oudh.

From maps of small areas we are able to estimate that the number of peaks existing in Himalayan regions, in cluding Kashmir and Bhutan, probably exceeds 40,000, and that of these more than 10,000 are always clothed with snow. Such estimates, rough as they are, suffice to show that the problem which confronted the Indian Survey when it first undertook the determination of the positions and heights of the peaks of the Himalayas was not a simple one.

It is difficult now' to discover how many of the 10,000 snow-peaks were known to the natives of India by name before the British commenced their survey. The number

3 Report on the Identification and Nomenclature of Himalayan Peaks. By Capt. H. Weod, R.E., with a preface by Colonel Gore, C.S.I., R.E. Longe, R.E. Surveyor Ge India. (Published by NO. 1828 , VOL. 7 I] so named was certainly small, and possibly less than fifty. Not only were the two highest mountains of all without a name but many of the most conspicuous peaks throughout the whole length of the Himalayas were nameless. The few peaks that serve as landmarks to travellers on frequented thoroughfares have probably always had names, and the few that mark the sources of sacred rivers and indicate to weary pilgrims on distant plains the positions of the shrines that are their goals have for ages been recognised by names.

It is questionable whether some of the Hindu names now attaching to peaks were not given in the first instance by British surveyors; in the earlier days of the survey names were accepted from villagers more readily, perhaps, than would now be done. Even the celebrated name of Dhawlagiri, as attaching to a particular peak, is not altogether free from suspicion. The story of the controversy over Mount Everest shows how easy it is to find native names that have no existence in fact, and how hard it is to identify the precise peak even when a native name is current.

When 10,000 snow-peaks have to be fixed, and when but $5^{\circ}$ of these have names, some system of classification has to be devised. The case is analogous to that of the stars; a few of the brighter stars have names of their own, the remainder are classified by constellations, and are designated by letters or numbers. The snow-peaks of the Himalayas are classified by areas, and are designated by Roman numerals or by letters with numbers attached thus the highest mountain in the world is known in the official records as Peak XV, and the second highest is recorded as Peak $K_{2}$, both having been nameless at the time of their discovery.

The height of Peak XV, now better known as Mount Everest, is 29,002 feet, and that of $K_{2}$ is $28,25^{\circ}$ feet. Sixty years ago Dhawlagiri, in Nepal, was considered the highest mountain in the world; Dhawlagiri is 26,795 feet high, and has since been found to be surpassed in height by six Himalayan peaks; of these $\mathrm{K}_{2}$ is in Kashmir, and the other five, Everest $(29,002)$, Kangchenjunga $I(28,146)$, Kangchenjunga II $(27,803)$, Makalu $(27,790)$, and Peak $T_{15}(27,000)$ are in or near Nepal.

The Discovery of Mount Everest. ${ }^{1}$-In 1848 trigonometrical surveyors commenced to build a line of survey stations along the plains of Oudh and Bengal from west to east, and to determine the positions of these stations in latitude and longitude by means of triangles observed with large theodolites. Sir George Everest had intended originally to carry the series along the mountains, but abandoned his design in consequence of the refusal of the Nepalese Government to allow the operations to enter their territories. Consequently, after crossing the hills of Kumaon, the stations were brought down into the plains near Bareilly, from which point they were carried for 800 miles through the deadly tracts which fringe the Himalayas. At almost every station the snowy range of Nepal was visible, and the northern horizon appeared broken by numbers of peaks. Just as some stars appear brighter to the eye than others, so do some snow-peaks against the sky-line appear loftier than others. The superior magnitude of certain stars may be due either to their greater diameter or their lesser distance, and the superior elevation of certain peaks may be due either to their greater height or their lesser distance. The most refined observations with the most perfect of instruments, if taken from a single station only, will furnish no clue as to whether a mountain-peak is conspicuous on account of its magnitude or on account of its nearness.

As the surveyors moved across Bengal from west to east they witnessed changes in the apparent positions of the peaks; the analogy of the stars no longer serves us, as owing to the great distances of the latter they appear to preserve their relative positions in the sky; but the case of mountain-peaks may be compared to what a traveller witnesses when he journeys by rail through a forest of pines-the nearer tree-trunks continually appear to pass between his eye and the more distant ones. As the surveyor moves across the plains parallel to the mountains he sees

1 In order to appreciate the distance from which Mount Everest is visible, seen from Land's End to Edinburgh and from Kent to Connaught. 
innumerable peaks, many snow-clad, many bare, always seemingly changing their places and forms.

It is a mistaken idea that particular peaks can be identified from different points of view by their characteristic shapes. Such a course may sometimes be possible from near stations, but at distances greater than forty miles the form of a peak is its cross-section in outline against the sky, and this changes as one moves round it. The same peak is often found noted in the field records of the survey by a different letter or number at each station from which it was observed. Colonel Sir Andrew Waugh, of the Bengal Engineers, who was Surveyor-General of India from 1843 to 1861 , realised from the outset the difficulties of identification. His orders were that every visible peak, great and small, was to be observed from every observing station, but that the identification of peaks, with the exception of the unmistakable few possessing native names, must be left to computers. In accordance with these orders the true direction of every visible peak and the angular elevation of every summit above the horizon were determined from every observing station.

The identification of the peaks as observed from different stations was then effected as follows:-

ist Step.-The stations of observation were carefully projected on a map, and from each were drawn lines representing the directions of all peaks observed from it.

2nd Step.-When direction-lines from three or more stations met in one point, it was tentatively assumed that the same peak had been observed on the three or more occasions.

$3^{\text {rd }}$ Step.-By trigonometrical formulæ the distance of this assumed peak from each of the observing stations was then calculated, and from these distances independent values of the latitude and longitude of the peak were obtained; if the several values were accordant the identification was proceeded with.

$4^{\text {th }}$ Step.-From the observed angle of elevation and from the calculated distance of the peak from each station the height of the peak was deduced; a separate value for the height of the peak was thus obtained from each observing station. If the several values of height were accordant the identification was finally accepted.

Numerous peaks were found to have been observed only once or twice, and could not be identified; many others failed to satisfy all the tests, and had to be rejected.

About 1852 the chief computer of the office at Calcutta informed Sir Andrew Waugh that a peak designated XV had been found to be higher than any other hitherto measured in the world. This peak was discovered by the computers to have been observed from six different stations; on no occasion had the observer suspected that he was viewing through his telescope the highest point of the earth.

The following table shows the several values of height that were obtained for Mount Everest:-

The Observed Height of Mount Everest.

Extracted from the Records of the Great Trigonometrical Survey of India.

\begin{tabular}{|c|c|c|c|c|c|c|c|}
\hline $\begin{array}{l}\text { Observing } \\
\text { station }\end{array}$ & 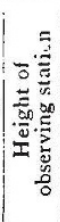 & 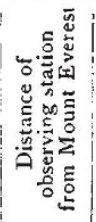 & $\begin{array}{c}\text { Date of } \\
\text { observation }\end{array}$ & : & 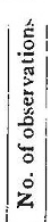 & $\begin{array}{l}\text { Observed } \\
\text { angle of } \\
\text { elevation }\end{array}$ & 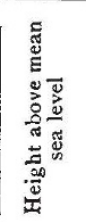 \\
\hline Jirol & $\begin{array}{l}\text { Feet } \\
220\end{array}$ & $\begin{array}{c}\text { Miles } \\
x 1866 \mathrm{x}\end{array}$ & Nov. 27,1849 & & 2 & is $5.333^{\prime \prime} 35$ & $\begin{array}{c}\text { Feet } \\
2899 \mathbf{r}^{*} 6\end{array}$ \\
\hline Mirzapur & 245 & $108 \cdot 876$ & Dec. $5,6,1849$ & 픔 & 12 & $2 \pm 16.66$ & $29005^{\prime} 3$ \\
\hline Janjpati & 255 & $108 \cdot 362$ & Dec. $8,9,1849$ & $\overline{\mathrm{Z}}$ & 4 & $\begin{array}{lll}2 & 12 & 9 \\
2 & 31\end{array}$ & $2900: \cdot 8$ \\
\hline Ladnia ... & 235 & $108.86 \mathrm{r}$ & Dec. $12, x_{49}$ & 0 & 4 & $2 \times 1125 ; 2$ & $28998 \cdot 6$ \\
\hline -Harpur ... & 239 & $111 \cdot 523$ & Dec. $17,18,1849$ & $\doteq$ & 8 & $2 \quad 624^{\circ} 9^{8}$ & $29026^{\prime} \mathrm{I}$ \\
\hline Minai & 228 & I $13^{\circ} 76 \mathrm{r}$ & Jan. 17,1850 & & & $22166 \mathrm{I}$ & $28990^{\circ} 4$ \\
\hline & ! & & & & & Mean ... & $29002^{\circ} 3$ \\
\hline
\end{tabular}

No. 1828 , VOL. $; 1\rceil$
Sir Andrew Waugh had always adhered to the rule of assigning to every geographical object its true local or native name; but here was a mountain, the highest in the world, without any local or native name that he was able to discover. He determined, therefore, to name the great snow-peak after Sir George Everest, his former chief, the celebrated Indian geodesist. The name of "Mount Everest" has since become a household word, and no objection to it has ever been raised by natives of the country. The Devadhunga Controversy.-When Sir Andrew Waugh announced that the peak was to be named Everest, Mr. Hodgson, who had been political officer in Nepal for many years, intimated to the Royal Geographical and Royal Asiatic Societies that Sir Andrew Waugh had been mistaken, and that the mountain had a local name, viz. Devadhunga. Sir Roderick Murchison, the president of the Royal Geographical Society, approved Waugh's action, but the Royal Asiatic Society supported Hodgson and repudiated the name of Everest. Seeing that the Survey officers had been debarred from entering Nepal, Mr. Hodgson was amply justified in raising the question he did; but he had made no scientific measurements, and it is known now beyond dispute that he was mistaken in his identification of Everest. He apparently assumed that the great peak, which he saw standing in the direction of Everest, and which was so conspicuous from Katmandu, where he resided, was the highest peak in Nepal $;{ }^{1}$ but Nepal covers a large area, and Mount Everest is more than a hundred miles from Katmandu. Either Mr. Hodgson was unaware of the real distance of Mount Everest, or he failed to realise that even the highest mountain on earth will look small at so great a distance. It is probable that $\mathrm{Mr}$. Hodgson never even saw Mount Everest; it is certain that if he did so he was unaware that he was looking at it.

All subsequent information goes to show that there is no peak in Nepal called Devadhunga. Mr. Hodgson's sincerity has never been doubted, and it is believed now that the name Devadhunga is a mythological term for the whole snowy range.

The Gaurisankar Controversy.-In 1854 three brothers, Hermann, Adolphe, and Robert de Schlagintweit, undertook a scientific mission to India and Central Asia at the instance of the King of Prussia, and with the concurrence of Lord Dalhousie and the court of directors. Their labours lasted until 1857 , by which date they had succeeded in taking numerous astronomical, hypsometric, magnetic, and meteorological observations; they had also made geological, botanical, and zoological collections for the India House Museum; and they had explored the high mountains of India and Tibet, and had constructed many panoramic drawings of the snow-peaks of the Himalayas. Their mission unfortunately ended in the death of the second brother, Adolphe, who was killed at Kashgar.

In 1855 Hermann de Schlagintweit visited a hill in Nepal named Kaulia, near Katmandu, and from it took observations to the snow-peaks. He saw the mountain called Devadhunga by Hodgson, and he identified it as Mount Everest ${ }^{2}$ he, however, repudiated Hodgson's name of Devadhunga, and certified that the local native name for the peak was Gaurisankar.

Continental geographers, accepting Schlagintweit's views, have continued to this day to call the highest mountain in the world Gaurisankar; the Indian Survey, however, were unable to reconcile Schlagintweit's results with their own, and have declined to follow him.

The diagram in Fig. I illustrates the tour of Hermann de Schlagintweit, who visited the two stations of Kaulia and Falut, which are 175 miles apart. From Kaulia he saw a high peak to the north-east which the natives called Gaurisankar, and which he identified as Everest. From Falut he saw a high peak to the north-west, which he also identified as Everest.

There is no doubt now that Schlagintweit was misled in his identification of Mount Everest. It is the common misfortune of all pioneers that posterity chiefly concerns itself with their mistakes. Indian geography owes much to Hermann de Schlagintweit, but she is more mindful now of his errors than of her debts. The mistakes of Schlagint- 
weit have formed the basis of controversy, and will continue to be remembered until controversy ceases.

In 1883 Colonel Tanner visited Falut, and found that Everest was barely visible from there, being almost shut out from view, and entirely surpassed in appearance by Makalu (height 27,790 feet), a lower though nearer peak; it was Makalu that Schlagintweit mistook for Everest, and it was Makalu that he drew as Everest, both in his panorama of the snows from Falut, and in his picture, which is preserved at the India Office.

In 1903 Captain Wood visited Kaulia by order of Lord Curzon; he found that Gaurisankar and Everest were

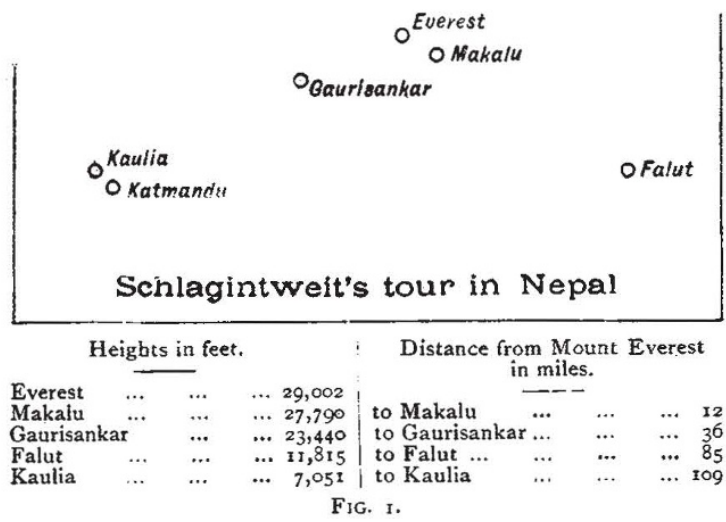

different peaks thirty-six miles apart, and that Everest, far from being conspicuous, was almost obscured from view by intervening ranges. Captain Wood also discovered that an imposing peak of the snowy range, a peak long known in the records of the survey as Peak XX, height 23,440 feet, was the famous Gaurisankar of the Nepalese.

A comparison of the drawings of Schlagintweit and Wood tells us that the same peak was shown by the Nepalese to both observers as Gaurisankar. Schlagintweit was therefore right in giving the name of Gaurisankar to the great peak that is so conspicuous from Kaulia and Katmandu, but he has been proved to have been wrong in three particulars, namely, (I) in his identification of Everest from Kaulia, (2) in his identification of Everest from Falut, (3) in assuming that he had observed the same peak from Kaulia as he had done from Falut.

It is interesting to consider the magnitudes of the mistakes he made:-from Kaulia the direction of Gaurisankar differs from the true direction of Everest by two degrees; from Falut the direction of Makalu differs from the true direction of Everest by forty-two minutes.

From Kaulia the elevation of Gaurisankar differs from the true elevation of Everest by twenty-four minutes; from Falut the elevation of Makalu differs from the true elevation of Everest by fifteen minutes.

The two peaks Gaurisankar and Makalu, which Schlagintweit thought were the same, are forty-seven miles apart.

The supposed identity of Everest and Gaurisankar has rested only on Schlagintweit's evidence. It is true that successive British Residents at Katmandu have continued to regard Gaurisankar as Everest, ${ }^{2}$ but their ideas have been based on the Schlagintweit tradition. It is also true that in a recent number of the Geographical Journal ${ }^{2}$ the photographs of Dr. Boeck have been preferred as evidence to the observations of the Indian Survey; unfortunately Dr. Boeck made a mistake of thirty-two degrees in direction in his attempt at identifying Mount Everest, ${ }^{3}$ and this initial slip led him to twist the whole area of Nepal round through a third of a right-angle.

Side Issues of the Controversy.-It is difficult to avoid the thought that this long controversy has of recent years been degenerating into a barren dispute over side issues.

(I) It has, for instance, been stated in the Geographical

1 "In the Himalayas," by Waddell, 1899, p. 346.

2 Geographical Journal, March, 1903.

3 Colonel Gore's yreface to Captain Wood's Report, 1904.

NO. I 828 , vOL. 7 I]
Journal that " the object of Captain Wood's visit to Nepal was to ascertain whether the mountain known as Mount Everest is visible from the heights in the neighbourhood of Katmandu, and forms part of the range known in Central Nepal as Gaurisankar." 1 But this statement is incorrect. The object of Captain Wood's visit to Nepal was to ascertain whether the peak known to the Nepalese as Gaurisankar was identical or not with the peak known to us as Mount Everest, and this main issue ought to be kept in view. It is also inaccurate to speak of a range in Central Nepal known as Gaurisankar: there is no range so known; Gaurisankar is a double peak.

(2) A side issue on which some argument has been expended is whether Mount Everest is visible from Kaulia or not. This point may be of interest to individuals, but it has no scientific importance; and I am surprised to see it asserted, as though some geographical issue were involved, that the Survey officers have generally held the view that Everest was not visible from Kaulia. ${ }^{2}$

In a paper published in I886, the late General Walker, R.E., gave some calculations of azimuth and elevation to show that the two peaks of Gaurisankar and Everest could not be identical; after proving his point in a convincing way, he added the following general remark :- " Obviously therefore Gaurisankar, the easternmost point of Schlagintweit's panorama of the snowy range, cannot have been Everest, and the great pinnacle must have lain hidden away from his view by intervening mountain masses." 3

If we wish to discover whether a place $A$ is visible from a place $B$, we have but two courses open to us: we can make calculations from contoured maps of the country, or we can send an observer to $B$ to ascertain if $A$ can be seen. If there are no maps, the second course alone is open.

Mount Everest is 109 miles from Kaulia; the intervening space is taken up by mountains and valleys, ridges and hollows, spurs and basins; this complicated area is unsurveyed, and questions of visibility are not mathematically arguable.

How came it, then, that an expert like General Walker expressed the opinion that Everest was not visible from Kaulia? General Walker was, of course, merely judging from Hermann Schlagintweit's recorded evidence. At Kaulia Schlagintweit made a careful drawing to scale of the snowy and nearer ranges; in Fig. 2 is given a copy of his drawing of Gaurisankar.

Schlagintweit wrote against the peak Gaurisankar on his drawing the words "Gaurisankar or Everest," but

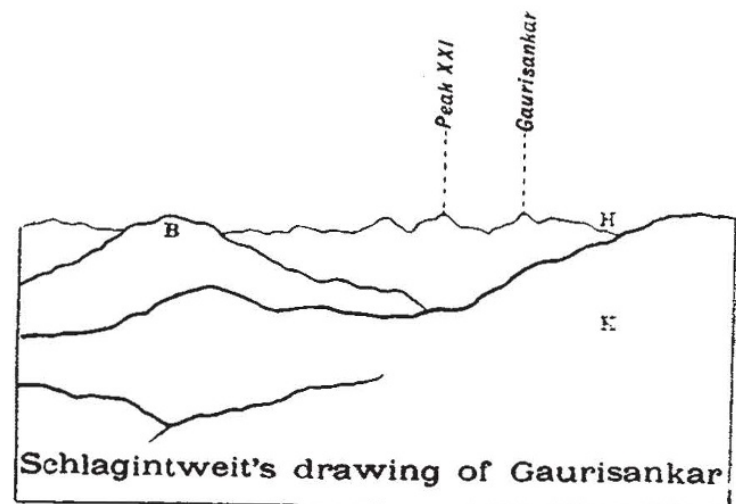

FIG. 2.

General Walker showed by calculations that if Everest had been really visible it would have been seen by Schlagintweit as a low peak near the spot marked $H$. As Schlagintweit showed no low peak at this spot, General Walker concluded that it had been obscured from his view by one or another of the many unsurveyed intervening ranges.

1 Geographical Journal, January, 1904, p. 89.

2 Geographical Journal, Marcb, 1903 , and January, 1904

3 Proceedings R.G.S., vol. viii., 1886, where it will be seen that Schlagintweit described Everest as the easternmost point of his panorama. 
When Captain Wood visited Kaulia in 1903 he was unable to discover the place from which Schlagintweit had made his drawing; he selected another spot, and made a careful drawing to scale of the snowy and nearer ranges. In Fig. 3 is given a copy of his drawing of Gaurisankar.

On the advice of the Prime Minister of Nepal, Captain Wood recorded on his drawing against the lower peak of the Gaurisankar double the name Gauri, and against its loftier companion the name Sankar.

If we compare Wood's drawing with Schlagintweit's, we see that the nearer range $B$ appears higher in Schlagintweit's picture than in Wood's. This same peculiarity is visible throughout the panoramas of the two observers; the near ranges appear in Schlagintweit's drawing higher always with regard to the distant ranges than they do in Wood's. The inference is that Schlagintweit drew his panorama from a considerably lower point than Wood did; this may account for the fact that Schlagintweit shows no signs of Everest.

Again, in Schlagintweit's drawing the near range $K$ cuts off laterally more of the snowy range than it does in Wood's, and obscures the shoulder of Gaurisankar just at the point where Everest should have been visible.

In Wood's drawing Mount Everest appears as a low peak at the spot where General Walker calculated that it would appear.

The omission of Everest from Schlagintweit's panorama led General Walker to believe that it was not visible from

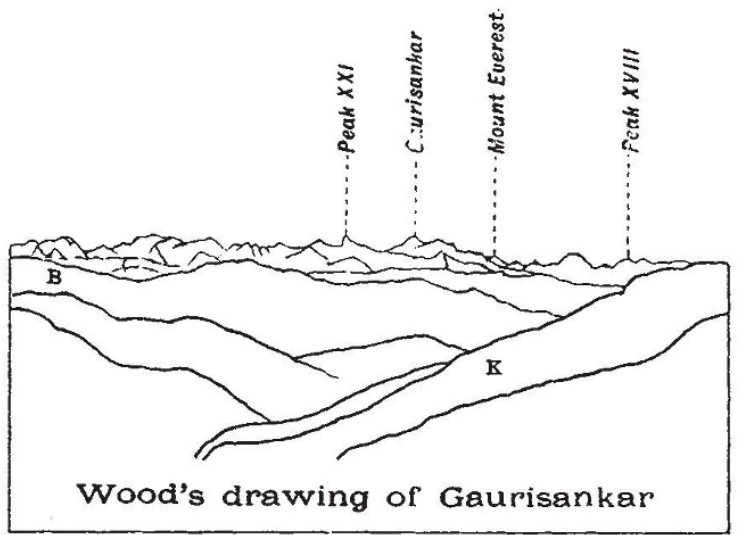

FIG. 3.

Schlagintweit's station at Kaulia. Whether it was visible or not was, I am sure, in General Walker's opinion not a question of moment.

(3) Now that Gaurisankar and Everest have been proved to be different peaks, a suggestion has been put forward that they belong after all to the same " group" of peaks, and that "according to Alpine usage and precedent there is nothing to prevent the name Gaurisankar being applied to the loftiest peak of the group."

It is clear from this passage that the author is desirous of getting rid of the name of Everest, but it is not clear how his object is to be attained, whether by iransferring the name Gaurisankar from the one peak to the other, or by giving the name Gaurisankar to both peaks. To displace the native name from the mountain which the natives know, and to attach it to a remote peak which they do not know, would be a course that would not commend itself to anyone interested in the preservation of local geographical names. To give the same name to both peaks would be to introduce a needless confusion.

Gaurisankar and Mount Everest, we are here told, belong to the same group; but what is a group? Controversialists give to the term different meanings to suit their own requirements. It is true that in some instances the same name has been given to different Himalayan peaks; Kangchenjunga I and Kangchenjunga II are the official designations of the two pinnacles which cap the lofty mass of Kangchenjunga; the eight peaks of a cluster in Kumaon 1 Geographical Journal, March, 1904, p. 362 .

NO. I 828 , vOL. 7 I] are named Badrinath I, Badrinath II, \&c. ; but these peaks are slight prominences crowning the snow-clad pyramid of Badrinath, like turrets on a castle. Everest and Gaurisankar are separated by a wide interval and a deep valley, and are not spires of a single pile.

The extent to which we are justified in giving the same name to different peaks is, however, not altogether question of intervening distance and depth; geographical significance has also to be considered. The peaks of the Badrinath cluster have a common, but no individual, significance; they are notable only as the several pinnacles of the sacred pile of Badrinath, and can therefore be classified without disadvantage under one general apellation. But the case of Gaurisankar and Everest is different: the former is remarkable in Nepal for the preeminence of its grandeur; the latter, screened from the gaze of man, is known only as the highest point of the earth. Would it not, then, be a mistake to include under one name two mountains the claims of which to celebrity are so different?

Before we blindly follow Alpine precedents in the settle ment of Himalayan problems, we must consider well whether the conditions are identical. "It is no exaggeration to say," writes a great Himalayan authority, "that along the entire range of the Himalayas valleys are to be found among the higher mountains, into which the whole Alps might be cast, without producing any result that would be discernible at a distance of ten or fifteen miles." 1

The Discovery of a Supposed Tibetan Name.-Colonel Waddell's book, "Among the Himalayas," gives a good description of the Nepalese mountains with many interesting profiles; the author's investigations have enabled him to authenticate a Tibetan name for a high peak which he believes to be Mount Everest. This name is Jamokangkar, sometimes spelt Chamokankar.

Now let us suppose for one moment that it will be proved by future evidence-not at present forthcoming-that the mountain called Jamokangkar by Tibetans is identical with our Mount Everest. What then? Will it be incumbent upon us to abandon the name of Everest and to adopt that of Jamokangkar? I think not.

When the Gaurisankar controversy opened, the name of Everest was an interloper upon the map of Asia; but its trespass has long since been condoned. Time and usage have secured for it a right not less sacred than the right of origin; for what, after all, is the right of origin but that conferred by time and usage? To displace now this name from its lofty position in geography would seem to many of us an outrage.

It will, I think, be lamentable if former advocates of the name Gaurisankar, seeing that their cause is doomed, continue the struggle under this new flag of Jamokangkar. Already, to our regret, has $\mathrm{Mr}$. Freshfield, a life-long defender of the claims of Gaurisankar, declared in favour of the Tibetan name. ${ }^{3}$

The old dispute has been settled; the names Gaurisankar and Everest have been proved to belong to different peaks; and it is to be hoped that Continental geographers, who have hitherto attached the name of Gaurisankar to the famous peak that we call Everest, will, in the interests of scientific harmony, now accept the name that has always been accepted by India. But before we can look for Continental acquiescence we must endeavour to show agreement at home. Few Continental geographers see the official reports of the Indian Government; the majority draw their conclusions from articles in our geographical Press.

In March, 1903, Mr. Freshfield, the late secretary of the Royal Geographical Society, wrote in the Geographical Journal as follows:- "The reason, for which the surveyors argued so strenuously forty-five years ago, that the 29,002 feet peak cannot be the Gaurisankar of Nepal was, of course, that their chief's proceeding in giving the mountain an English name was excused, or justified, at the time by the assertion that it had no local or native name."

The surveyors whose motives $\mathrm{Mr}$. Freshfield has impugned were formed into a committee forty-five years

1 See the article on Himálaya by General Sir R. Strachey, R.E., in "Encyclop. Brit.," gth edition.

Published 1899.

3 Geosraphical Journal, March, 1904, p. 363. 
ago to consider the question whether the peak which $\mathrm{Mr}$. Hodgson called Devadhunga was identical with the peak which Sir A. Waugh called Mount Everest; from the geographical evidence available they concluded that the two peaks were not identical, and their conclusion has been found correct. ${ }^{2}$ In those early days there had arisen no such subtle questions as whether Mount Everest formed part of a certain range, or whether it belonged to a certain group of peaks, or whether it was just visible to those who knew where to search for it. To the clear minds of our predecessors, to Hodgson and Waugh and Schlagintweit and Walker, there was but one question at issue, namely, the identity of Hodgson's and Schlagintweit's peak with the Mount Everest of the Survey.

This question has now been answered, and after fifty years of discussion the Hindu and Nepalese names have been proved to be inapplicable; let us, then, close a controversy that has fulfilled its purpose, and let us suffer the English name to rest on our maps in peace.

\section{S. G. BurRard.}

\section{UNIVERSITY AND EDUCATIONAL INTELLIGENCE.}

OXFORD.-.The Vice-Chancellor has appointed Prof. Ray Lankester, hon. fellow of Exeter College, to be Romanes lecturer for 1905 .

Sir John Burdon Sanderson, Bart., hon. fellow of Magdalen College, late regius professor of medicine, has been constituted a perpetual delegate of the university museum.

Mr. Walter J. Barton, scholar of New College, has been elected to the geographical scholarship for 1904-5.

The executive committee of the Oxford division of the British Medical Association has had the electric light permanently installed in the Pitt-Rivers Museum as a mark of their appreciation of the generosity of the university in allowing the association to make use of their various buildings and of the help the university gave them in other ways during the meeting of the association in Oxford in July last. The cordial thanks of the university have been conveyed to the Oxford division of the association for their most acceptable gift, and the curators of the university chest have been empowered to erect a suitable record of the occasion in the Pitt-Rivers Museum.

Cambridge.--Mr. J. C. Willis, of Gonville and Caius College, director of the botanic garden at Peradeniya, Ceylon, has been approved for the degree of doctor of science.

Prof. G. H. Darwin, F.R.S., and Mr. A. E. Shipley, F.R.S., have been elected members of the council of the Senate.

Mr. A. Young, tenth wrangler in 1895 , lecturer in mathematics at Selwyn College, has been elected a fellow of Clare College.

Mr. R. P. Gregory, demonstrator of botany, and $\mathrm{Mr}$. E. Cunningham, senior wrangler 1902, have been elected fellows of St. John's College.

Prof. Marshall Ward, F.R.S., has been elected president, and Prof. Thomson, F.R.S., Prof. Liveing, F.R.S., and Dr. Hobson, F.R.S., vice-presidents of the Cambridge Philosophical Society.

WE learn from Science that the will of $\mathrm{Mr}$. James Callanan, of Des Moines, makes bequests amounting. to $27,000 \mathrm{l}$. for educational institutions. Of this sum $20,000 l$. goes to Talladega College, Alabama.

THE chair of chemistry applied to the dyeing industry at the Paris Conservatoire des Arts et Métiers, rendered vacant by the death of $M$. Victor de Luynes, has been given, states the Athenaeum, to M. Maurice Prudhomme, who acted as reporter of the section devoted to textile industries and dyeing at the Exposition Universelle of 1900.

THE following deans of faculties of the University of London have been elected for the two years 1904-6:medicine, Dr. J. K. Fowler; science, Dr. A. D. Waller, F.R.S. ; engineering, Prof. J. D. Cormack; economics, Mr. G. Armitage-Smith.

$$
1 \text { Vide Proceedings R.G.S., } 1858 \text {. }
$$

NO. 1828 , VOL $7 \mathrm{I}$ ]
Mr. Andrew Carnegle, who has been Rector of the University of St. Andrews for the past term of three years, was re-elected to that office on November 4 .

AN open competitive examination for not fewer than twenty situations as assistant examiner in the Patent Office will be held by the Civil Service Commissioners in January next. The examination will commence on January 2, 1905, and forms of application for admission to it are now ready for issue, and may be obtained on request addressed by letter to the secretary, Civil Service Commission, Burlington Gardens, London, W.

DR. C. KASSNER has been appointed professor of meteorology at the Berlin Technical College; Dr. Maurer physicist to the German Navy; Dr. O. Lummer, from Charlottenburg, to succeed Prof. O. E. Meyer as professor of physics at Breslau; Prof. London, of Breslau, to succeed Prof. Heffter as professor of mathematics at Bonn. Dr. Augustin, of Prague, has been raised to the rank of ordinary professor of meteorology, and Dr. Karl Exner has retired from the chair of physics at Innsbruck with the title of Hofrat.

IN view of the importance of German to students of science, the University College of North Wales founded a lectureship in German, to which was attached the duty of conducting a beginner's class in that language, with especial reference to the needs of students qualifying for science degrees, and Mr. Rea, of Belfast, was appointed lecturer. The experiment bids fair to be a complete success, about thirty students having joined in the first year of the new venture. The institution of classes of this kind in our university colleges will, it is hoped, remove an anomaly which, in the natural order of events, has grown up in Britain, viz. the turning out of graduates in science who are debarred from efficiently engaging in post-graduate work by their inability to assimilate readily the subjectmatter of Continental scientific literature.

\section{SOCIETIES AND ACADEMIES. LONDON.}

Royal Society, June 2.-"Studies on Enzyme Action : The Effect of 'Poisons' on the Rate of Decomposition of Hydrogen Peroxide by Hæmase." By George Senter, Ph.D., B.Sc. (Lond.). Communicated by Prof. E. H. Starling, F.R.S.

In a former paper (Zeit. physikal. Chemie, xliv., p. 257, 1903) the author investigated the relation of the reaction velocity to peroxide concentration and amount of enzyme present, as well as the acceleration caused by rise of temperature; the results correspond almost exactly with those obtained by Bredig in his experiments on the decomposition of hydrogen peroxide by colloidal platinum. In the present paper, assuming that hæmase is also a colloid in solution, it is suggested that the velocity of reaction between the catalysor and hydrogen peroxide is great in comparison with the rate of diffusion of the peroxide to the colloidal particles, so that what is measured is really a diffusion-velocity. This would account for the analogous results obtained with platinum and hæmase, since the nature of the catalysor would be of secondary importance.

The hæmase catalysis of hydrogen peroxide, like the platinum catalysis, is retarded by small quantities of many substances, more especially by those which act as poisons towards the living organism. Thus mercuric chloride, sulphuretted hydrogen, and hydrocyanic acid, in the concentration of I gram-molecule to 1 million litres, reduce the reaction-velocity to half its value; they are just the substances which have the greatest retarding effect on the platinum catalysis. Iodine, mercuric cyanide, and aniline have a much smaller effect. Arsenious acid, sodium fluoride, and formaldehyde do not greatly retard the catalysis; although powerful antiseptics, they have little effect on enzyme actions in general. Carbon monoxide, although an active poison for the platinum catalysis, does not affect hæmase. Hæmase, like other enzymes, but unlike platinum, is very sensitive even to minute quantities of acids and alkalis. The retarding effect of acids is, in most cases, proportional to the concentration of hydrogen ions, in other words, to the strength of the acid. The ways in which 